\title{
LAS CIUDADES EN EL CINE DE ALFRED HITCHCOCK. UNA APROXIMACIÓN A LOS ESTUDIOS FÍLMICOS DESDE EL AMBITO DE LA GEOGRAFÍA
}

\author{
The Cities in Alfred Hitchcock's movies. \\ An approach to film studies from the field of Geography
}

\author{
Aurelio Nieto Codina ${ }^{1}$ \\ Recibido: 20/02/2013 Aceptado: 19/05/2013
}

Resumen. En este artículo se proponen pautas en relación a la influencia de lo audiovisual en nuestra percepción de la ciudad, seleccionando para este objetivo algunas películas de Alfred Hitchcock. La relación del cineasta con la ciudad es ambivalente, unas veces muestra la ciudad como fuente de referencias emblemáticas, mientras en otros casos no duda en estigmatizar la ciudad tradicional compacta (centros urbanos tradicionales) y apostar por modelos de urbanismo extensivo (periferias urbanas). Se describe también una nueva forma de turismo urbano, que explota los escenarios que aparecen en las películas como recurso turístico.

Palabras clave: Percepción, cine, ciudades compactas, periferia urbana, imagen, turismo urbano.

Abstract. In this paper we propose guidelines regarding the influence of the audiovisual in our perception of the city, selecting for this purpose some of Alfred Hitchcock's movies. The filmmaker's relationship with the city is ambivalent, sometimes shows the city as a source of symbolic references, while in other cases does not hesitate to stigmatize traditional compact city (downtowns) and go for extensive planning models (suburb). It also describes a new form of urban tourism that exploits the scenarios that appear in movies as a tourism resource. Key words: Perception, movies, downtown, suburb, image, urban tourism. 


\section{INTRODUCCIÓN}

La relevancia de las películas de Alfred Hitchcock se ha incrementado últimamente, sobre todo cuando la revista Sight and Sound, en sus votaciones anuales, ha seleccionado Vertigo (figura 1) como la película mejor valorada por los críticos ingleses de los últimos años².

Como todo gran artista, la obra cinematográfica de Hitchcock está llena de aspectos aún por descubrir ${ }^{3}, y$ uno de ellos es la presencia de la ciudad y el urbanismo en el conjunto de su cine, que abarca desde sus inicios en el mudo allá por 1927 hasta su postrera realización americana en 1975. Como se puede apreciar, se trata de un arco cronológico bastante amplio que Ilena casi medio siglo, y que gracias a ello permite a su autor ser testigo de cambios fundamentales en el urbanismo contemporáneo. Hitchcock conoce los rescoldos del Londres victoriano en su infancia y juventud, asiste al desarrollo vertical en forma de rascacielos de los centros urbanos norteamericanas en el periodo de entreguerras y experimenta, con agrado, el crecimiento suburbial de los barrios de viviendas unifamiliares en la segunda mitad del siglo $X^{4}$.

Se trata por supuesto de un espectador privilegiado. Al interés del director por la arquitectura, hay que unir su pasión como coleccionista de arte moderno, como puso de manifiesto la exposición auspiciada por el Museo de Bellas Artes de Montreal en 2002, que desvelaba por primera vez la colección privada de pintura del director, con obras de artistas tan dispares como Caillebotte, Klee, Hopper, Magritte o Dali ${ }^{5}$. Curiosamente, estos artistas también dejaron un discurso visual sobre la ciudad moderna, la urbe llena muchas de las obras pictóricas de estos artistas, sobre las que proyectan luces y sombras.

En este artículo vamos a reflexionar sobre imágenes cinematográficas, ya que como señaló Delleuze: los grandes cineastas piensan con imágenes, como si fueran una mezcla de pintores y filósofos ${ }^{6}$. Partiendo de esta premisa, las películas del director inglés nos pueden ayudar en varios sentidos; por ejemplo, a entender la evolución de la imagen de la ciudad a lo largo del siglo XX; también, a descubrir posible patologías relacionadas con la vida urbana; $y$, sobre todo, en el ámbito simbólico, son una fuente fundamental para identificar lugares memorables del imaginario colectivo de los espectadores, reaprovechados y reinventados por el turismo actual.

Antes de entrar de lleno en el centro de nuestro tema (el imaginario visual hitchcokiano sobre la ciudad), quiero dedicar un pequeño apartado a algunos aspectos relativos

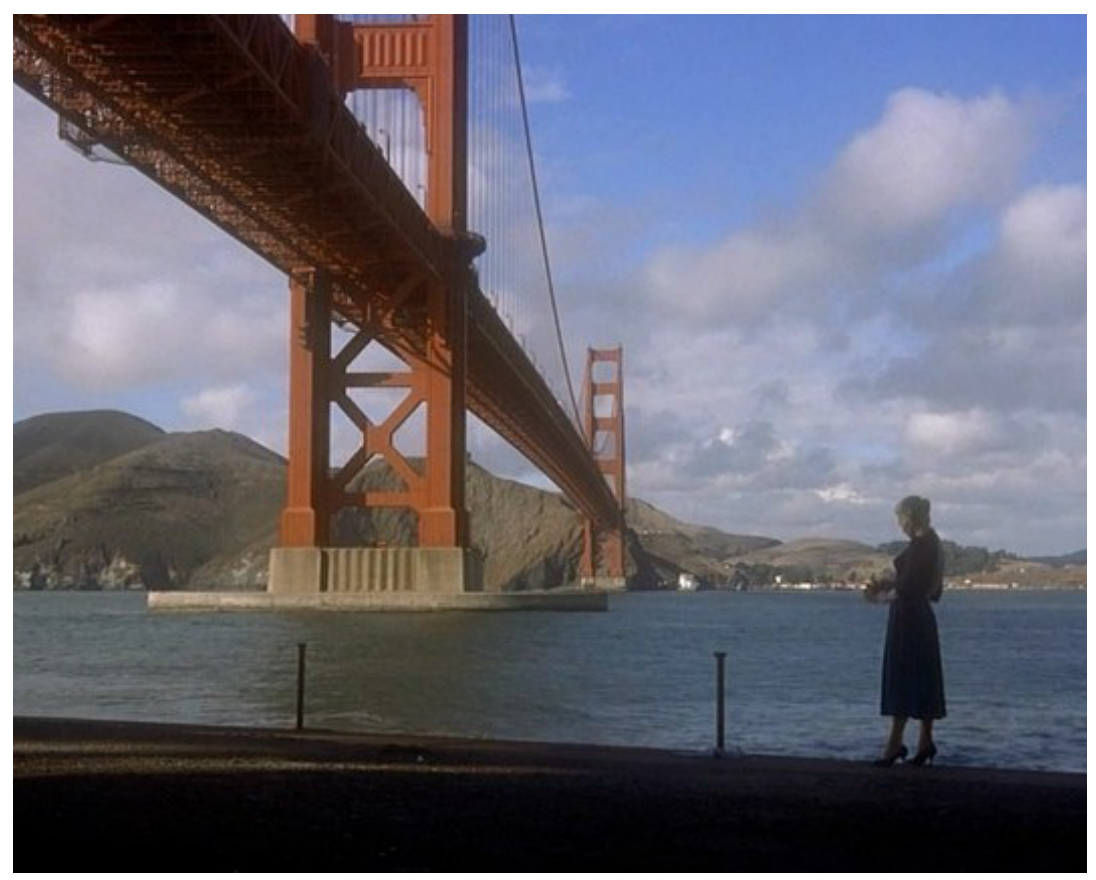

4 Figura 1. El Golden Gate y la bahía de San Francisco en Vertigo. Fuente: DVD, Universal Pictures.

$\left({ }^{2}\right)$ Aunque estas votaciones no dejan de ser un juego, sirven de todos modos como un índice de tendencias. El listado completo de 2012 se puede consultar en:

http://explore.bfi.org.uk/sightandsoundpolls/2012

(3) Dejamos fuera de este estudio sus películas para televisión, los trailers comerciales y su documental sobre los campos de exterminio nazi (no distribuido).

(4) En América suburbio es sinónimo de desarrollo urbano en la periferia.

(5) Esta exposición quedó plasmada en un interesante catálogo coordinado por PAÏNI, D.; COGEVAL, G. ed. (2000), que nos invita a explorar y descubrir, con sorpresa, el paralelismo entre las imágenes filmadas por Hitchcock y algunas imágenes del gran arte moderno y contemporáneo. Por supuesto, este material ha servido de gran ayuda para las reflexiones expuestas en este artículo.

(6) DELLEUZE, G. (1984), pág. 12 
a la percepción de la imagen de la ciudad, siempre desde el punto de vista de un geógrafo.

\section{EL CINE, LOS GEÓGRAFOS Y LA PERCEPCIÓN DE LA CIUDAD}

La incorporación del cine y los medios audiovisuales en el discurso de los geógrafos es relativamente tardia ${ }^{7}$; a modo de compensación, parece que en fechas recientes se está produciendo un renovado interés hacia este campo de estudio ${ }^{8}$. Pero, ¿qué utilidad tiene para un geógrafo seleccionar un conjunto de películas y establecer con ellas un discurso a propósito del paisaje urbano contemporáneo ${ }^{?}$.

Evidentemente, el panorama audiovisual presenta hoy un desarrollo de tal dimensión, que parece que todo lo que no sea expresado con imágenes en movimiento no adquiere relevancia para la conciencia social colectiva. Ante esta evidencia, el geógrafo debe acercarse a los diferentes medios audiovisuales (cada vez más diversificados) para detectar temáticas novedosas de investigación, para indagar cómo se presenta el espacio urbano en las dinámicas cotidianas, y para descubrir los aspectos simbólicos que dominan el imaginario ciudadano colectivo.

A falta de una metodología más precisa y consensuada para incorporar lo cinematográfico a los estudios geográficos, debemos confiar en la intuición, y documentar todas las propuestas desde una visión amplia que considere lo realizado en otras disciplinas como la antropología, la psicología, la filosofía o la historia del arte. Finalmente, es indispensable acudir a un método comparativo en el que se confronten las imágenes fílmicas con imágenes procedentes de otros medios plásticos.

Lo que no se puede pretender es limitar la investigación a la recopilación de las temáticas enunciadas en las películas, o a enumerar aspectos argumentales útiles para nuestro propósito, estos procedimientos ya se emplearon en los trabajos pioneros de los años noventa que utilizaron los medios audiovisuales como fuentes para el análisis geográfico ${ }^{10}$. Creo que debemos indagar qué nos dicen las películas y cómo nos lo dicen, reconsiderar la dimensión literaria del cine y profundizar en sus posibilidades expresivas visuales y sonoras.

A pesar del esfuerzo, siempre nos movemos en un terreno limitado metodológicamente, ya que lo que ofrecemos son imágenes fijas, cuando el objeto que estamos analizando se define por lo cinético. Nos enfrentamos en estudios de este tipo a unos productos culturales que desarrollan lo visual en el tiempo, que manipulan y estilizan la experiencia del tiempo real (mediante cambios de plano, movimientos de cámara, elipsis visuales, etc.), creando una realidad de tipo virtual. De igual modo se altera el sentido del espacio, ajustándolo a las necesidades de expresión de cada película ${ }^{11}$.

Todos estos aspectos son muy importantes, ya que hoy nos movemos en una cultura eminentemente audiovisual. Pero esta constatación no puede hacernos caer en posiciones moralista sobre las bondades o defectos de los nuevos medios, una opción en la que se incluyen ensayistas tan perspicaces como Susan Sontag y Paul Robinson, pioneros en estudiar esta nueva realidad audiovisual. El discurso desarrollado por estos autores deriva e incide en las limitaciones educativas de la imagen, considerándola sólo como una fuente de sensaciones, como un mero espectáculo generador de estímulos, nunca como elemento de aprendizaje ni de conocimiento, muchos menos de reflexión. En el fondo, estos análisis o creencias enlazan con las teorías platónicas que consideraban que la vista no debía considerarse una fuente de sabiduría. Según este planteamiento, las maravillas y los engaños de lo visual son importantes como un primer paso para llegar al verdadero conocimiento, que debe quedar limitado al razonamiento mental. "Estrictamente hablando es dudoso que una foto nos ayude a entender algo", señala Susan Sontag, ya que es una imagen que está condicionada por el encuadre, la luz, los gestos y todo un añadido estético que no ayuda al conocimiento intelectual ${ }^{12}$. Si comparamos esta postura con lo expresado al comienzo de nuestro artículo, en que recogíamos una cita de Gilles Deleuze, tenemos servida la polémica. De todos modos, para el propósito de este artículo: reflexionar sobre el paisaje urbano y las personas que lo habitan, nos es más fructífero seguir el planteamiento del filósofo francés.

(7) TUAN, Y. F. (1979), constata las dificultades y las limitaciones del uso de lo "visual" en las explicaciones geográficas, en una disciplina que curiosamente está muy determinada por el sentido de la vista.

(8) Al menos en el ámbito de la geografía española, y a partir de 2003, tenemos varios artículos interesante realizados por J. Costa y A. Gamir Orueta (ver bibliografia).

( ${ }^{9}$ S Sin olvidar que todo lo expresado alrededor de esta propuesta debe ser contextualizado en un momento histórico preciso. Sobre la importancia de la dimensión histórica en los estudios del moderno paisaje urbano nos remitimos al trabajo ya clásico de RELPH, E. (1987), The Modern Urban Landscape.

$\left({ }^{10}\right)$ Aspectos puestos de manifiesto en: KENNEDY, Ch.; LUKINBEAL, Ch. (1997). "Towards a holistic approach to geographic research on film", Progress in Human Geography, 21, pp. 33-50.

Casi todos los trabajos geográficos aqui reseñados se acercan al cine como fuente de argumentos, como si se tratase de textos literarios o teatrales.

(11) La diferencia entre espacio real y espacio fílmico genera dos formas diferentes de cartografiar el mundo. Este tema está desarrollado en: GAMIR ORUETA (2012).

(12) La cita de Susan Sontag aparece en: TUAN (1979), p. 418. 
Para valorar el impacto del cine en nuestros esquemas perceptivos, tenemos que partir del siguiente principio: el cine es un forma de expresión en la que todo es real, aunque proceda de una reconstrucción o de un decorado, al ser visualizado tiene una dinámica propia que lo hace real a ojos del espectador. Se trata por tanto de un medio que produce escenarios atractivos para el geógrafo, al informar del sentido de la espacialidad desarrollado por diferentes culturas o generado en diferentes momentos históricos. Jean-Paul Sartre, en un alarde de determinismo ambiental, decía que los escenarios proyectados en las películas tienen una presencia más vibrante que los personajes, "el film pinta al hombre que está en el mundo y condicionado por él"13, una frase extrema pero que acierta a mostrar las posibilidades de expresión geográfica del medio cinematográfico.

La percepción de la realidad urbana es un proceso en principio fisiológico que va de los objetos del paisaje a los órganos perceptivos, para a continuación generar un conjunto de imágenes simbólicas que permiten al individuo interactuar en su medio mediante respuestas con diversos grados de complejidad. Pero, este proceso no se limita a este simple esquema, ya que mediante una retroalimentación todas las imágenes asimiladas por el individuo actúan además como filtros, que actúan cada vez que volvemos a enfrentarnos con la realidad. La percepción no parte de cero, tiene en cuenta todo lo asimilado previamente por muy diferente fuentes; así, según estos principios se puede presentar un modelo de percepción.

En la figura 1 se muestra un posible modelo de percepción sugerido por B. Goodey ${ }^{14}$.

Brevemente, se puede decir que: la imagen que el individuo se crea surge de su espacio personal, del conoci- miento del entorno cercano que mejor conoce (habitaciones del hogar, mobiliario, calles recorridas habitualmente), de los desplazamientos habituales hacia el lugar de trabajo, 0 a los centros de compra, de diversión, etc. Estos espacios proporcionan información sobre localizaciones, conexiones entre lugares, caracteres de las construcciones, y significados socioeconómicos, culturales o de cualquier otra índole. La información recibida a través de los contactos personales y de los medios de comunicación (televisión, cine y radio) es el último complemento que cierra este esquema perceptivo. De este modo, los mecanismos fisiológicos y psicológicos ofrecen una información que se va fragmentando en función de la lejanía de los espacios visitados, todo ello filtrado por los prejuicios y los estereotipos mentales. Este modelo es muy útil como marco general, ya que presenta al ciudadano como espectador, como un receptor de información procedente de diversos medios.

Desde sus orígenes el cine ha influido en la psicología de las masas, lo visto en el cine (hoy diríamos en las pantaIlas, ya que estas se han diversificado) facilita la creación de modas, posibilita también que se copien actitudes personales, vestuarios, tendencias estéticas, etc. La realidad cada vez más imita la ficción. El dilema es delimitar hasta qué punto influye lo visto en las pantallas, evidentemente este hecho es difícil de cuantificar, pero en ningún caso se puede negar su existencia. La cultura visual de masas propone una serie de valores que, operando a través de símbolos, generan un repertorio de estereotipos fáciles de asimilar ${ }^{15}$. Por supuesto, en este conjunto de estereotipos se incluyen la arquitectura y el urbanismo difundidos por el cine ${ }^{16}$, fuente de sensaciones sobre lugares a los que tal vez no se tenga acceso más que por esta vía.

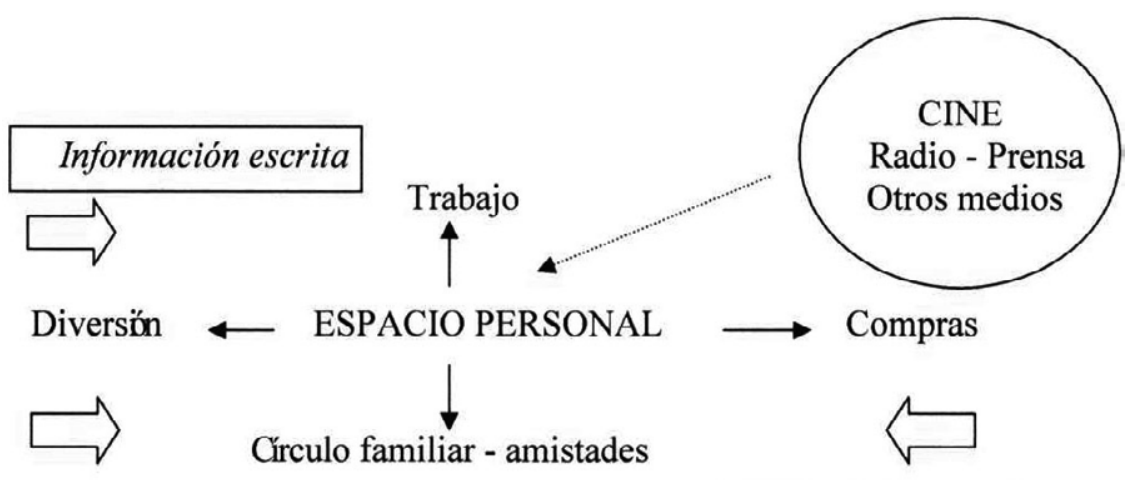

Información visual

Información oral

4 Figura 2. Modelo de percepción de B. Goodey.

(13) La cita de Sartre está recogida en: TUAN (1979), op. cit., p. 422.

(14) GOODEY, B. (1973). "Perception of environment". Ocasional Papers, 17, University of Birmingham. Citado en: ZÁRATE, A. (1991). El espacio interior de la ciudad, Madrid, Sintesis, p. 176-177.

(15) Diferentes autores coinciden en este punto, por ejemplo: SUSMAN, W. (1973) Culture as History. The Transformation of A American Society in The Twentieth Century, New York, Pantheon Books, p. 160. GANDINI, L. (1994). L'immagine della città americana nel cinema hollywoodiano, 1927-1932, Bologna, Clueb, p. 11.

(16) Aspectos estudiados en: RAMÍREZ, J. A. (1986). 


\section{DEFINIENDO LAS CIUDADES EN EL CINE DE ALFRED HITCHCOCK}

Los resortes narrativos del cine responden a unas estructuras expresivas que convierten la experiencia cinematográfica en un "viaje inmóvil", los procedimientos para realizar este viaje deben ser "controlados por cada espectador como competencia indispensable para la vida social moderna" 17.

Noël Burch ha expresado muy bien como el cine es una experiencia cómplice entre director y espectador, ya que ambos comparten unos recursos expresivos que hacen accesible el entendimiento de lo que se narra en las películas ${ }^{18}$. De manera primaria, lo que se busca en un espectáculo cinematográfico es que el público viaje sin moverse del asiento.

Esta metáfora del viaje es plenamente geográfica y fundamental en la obra del director inglés. Desde su primer film, entiende que el contexto de la vida urbana identifica al espectador con lo narrado y, por tanto, el movimiento de los personajes tanto dentro del entramado urbano como entre diferentes ciudades, combinado con los cambios de escenario que muestran ambientes urbanos diversos, es clave para lograr el encantamiento del público y, al mismo tiempo, la implicación del mismo en la narración. Cuando actúa a la inversa, limitando los escenarios o presentándolos de manera muy estilizada (Rope, Dial M for Murder); es decir, cuando aplica recursos más vanguardistas, o antinaturalistas, que alteran los mencionados "recursos expresivos compartidos", se produce una disminución en el favor del público. Un aspecto que debían cuidar mucho los artistas del cine clásico porque en ello les iba la continuidad de su trabajo ${ }^{19}$.

El viaje del cine de Hitchcock por el mundo de las ciudades contemporáneas tiene sus limitaciones, ya que básicamente los escenarios corresponden al ámbito inglés (Londres) o a norteamericano (Nueva York, San Francisco, etc.), en muy pocos casos nos situamos en ciudades de otros continentes. En estos casos, casi siempre se trata de planos recurrentes muy poco elaborados (Marraquech en The Man Who Knew Too Much o La Habana en Topaz, en los dos ejemplos se recurre a sobreimpresiones y a planos rodados por la segunda unidad). En términos generales la ciudad en el cine de Hitchcock, como en casi todo el cine clásico, es un trasfondo con valor contextual, la información que se da de la ciudad es escasa y fragmentada, en primera instancia lo que se busca es la ubicación del espectador, no una valoración de los espacios urbanos como se hace en películas documentales o divulgativas centradas en estos temas. Un plano del Big Ben o el London Bridge bastan para saber que estamos en Londres, y a partir de ahi arranca la trama.

Los planos generales que nos remiten a la ciudad son muy específicos, limitados en el metraje total de las películas y con un fuerte contenido simbólico o emblemático, ya que se pretende que unas pocas imágenes sirvan como referencia a un todo muy dificil de abarcar. Es significativo el uso de sinécdoques visuales para lograr este objetivo (véase la figura 9).

¿A qué se debe esta característica? Creo que responde a una motivación doble, tanto a motivaciones técnicas como ideológicas. Estas dos premisas han sido muy bien expuestas por Pierre Sorlin ${ }^{20}$ y aunque en términos generales comparto sus opiniones, creo que se deben matizar cuando se acude a los ejemplos concretos, sobre todo en referencia a cinco películas de las que hablaré más adelante.

Es evidente que los rodajes en las calle son muy complicados y siempre han sido una fuente de problemas en cualquier producción cinematográfica, Hitchcock prefería el rodaje en estudios aunque no desdeñó los escenarios natu-

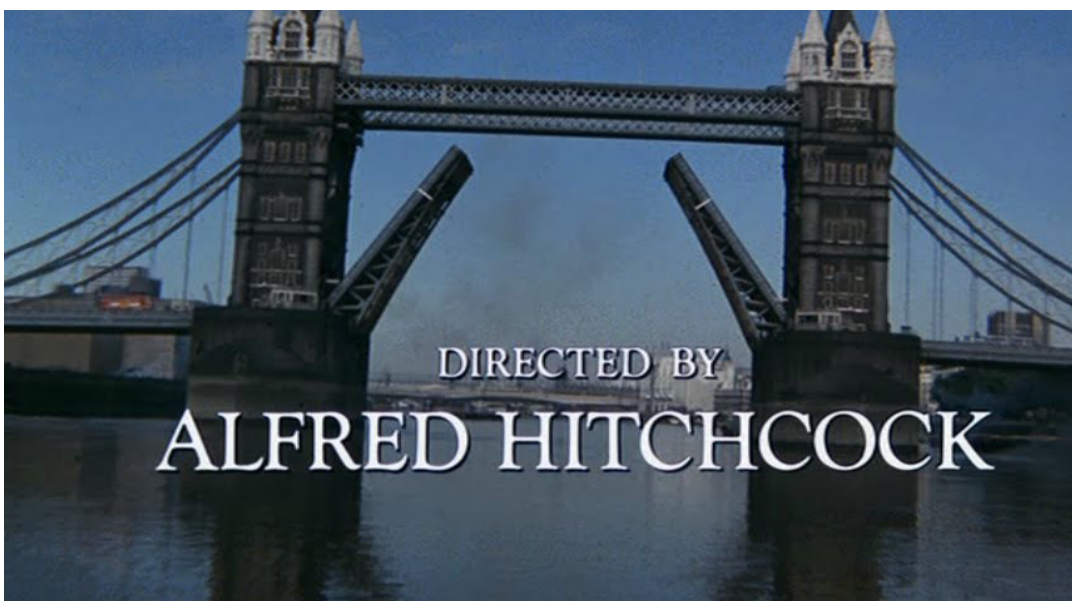

FIGURA 3. Títulos de crédito de Frenzy. Fuente: DVD, Universal Pictures.

(17) BURCH, N. (1987), pág. 231

${ }^{18}$ Las diferencias entre un viaje en la vida real y un viaje en la sala cinematográfica, con sus interesantes repercusiones geográficas, se analizan en: GAMIR ORUETA, A. (2012)

$\left.{ }^{19}\right)$ Lo que no significa que sean películas insignificantes, algunos estudiosos del cine, como Nöel Burch, tienen en alta estima estas películas.

(20) SORLIN, P. (2001), pág. 22. 
rales, siempre que aportasen los efectos estilísticos por él buscados. En otros casos, la elección se debe a imperativos ineludibles de la producción. Las dificultades de los rodajes en escenarios naturales urbanos son de sobra conocidas. Parece ser que en el rodaje de I Confess más de ocho mil personas observaron a Hitchcock mientras grababa las escenas con Montgomery Clift y Anne Baxter en el paseo por el río San Lorenzo y cruzando de una orilla a otra en el Lévis Ferry de Quebec City ${ }^{21}$.

La primera película de Hitchcock que recurre al rodaje en escenarios naturales de forma plena lo fue porque las condiciones económicas así lo aconsejaban, en definitiva, se trataba de razones de ahorro. Me refiero a The Shadow of a Doubt, creada en un momento con graves dificultades para el suministro de material de construcción (la Segunda Guerra Mundial), lo que aconsejaba reducir la fabricación de sets al mínimo. Esta película es capital para el tema que estoy tratando.

En otros casos, como Frenzy, son más determinantes los gustos del público de la época, ya que en los años setenta las audiencias eran poco receptivas a los trucajes visuales. En un caso excepcional, The Wrong Man, los escenarios naturales neoyorquinos parecen ser una influencia del neorrealismo italiano y la aparición de gustos estéticos renovados que apostaban por la veracidad. Se puede decir que Hitchcock buscaba en estos casos estar a la moda ${ }^{22}$. En esta película, hay un especial cuidado por representar localizaciones muy concretas pero de escasa relevancia para los no residentes en Nueva York. La cotidianeidad del residente podría ser la clave de esta obra, en un guiño a las prácticas de verosimilitud que sus colegas italianos, con Rossellini y Zavattini a la cabeza, realizaban en Italia. En The Wrong Man identificamos las estaciones de metros de la Quinta Avenida, la prisión federal, los Jacksons Heights de Queens y el sanatorio Gree- mont, donde ingresa la trastornada esposa del protagonista en la última secuencia del film. También aparecen locales nocturnos de moda en los años cincuenta como el Stork Club situado entre la $3^{\mathrm{a}} \mathrm{Av}$. y la calle 53 . El cuidado en hacer ver al espectador donde se localizan los acontecimientos de esta película es extraordinario, aunque se trata de un ejemplo aislado en el conjunto de su obra, en la que predominan los decorados construidos en estudio y el uso emblemático de lugares reconocidos a nivel mundial.

$Y$ es que las ciudades de Hitchcock son el resultado de una mezcla en la que se combinan escenarios naturales, arquitecturas de interior y fachadas construidas en los platós de Hollywood, maquetas hechas a escala, sobreimpresiones de actores sobre fondos pregrabados ${ }^{23}$ y planos trucados con cristales coloreados, para los que contó con la ayuda de un artesano excepcional: Albert Whitlock. A este respecto y como ilustración del trabajo de este colaborador, veamos dos planos de la película Frenzy.

En la figura 4, mediante un plano cenital, se nos presentan las labores de carga y descarga de una frutería en el antiguo mercado del Covent Garden londinense, se trata de un plano similar a los que aparecen en el cine realista y pegado a la más rutinaria cotidianeidad.

En la figura 5, el mercado del Covent Garden se ha reconstruido de manera virtual, con imagen real y una zona oscurecida mediante vidrios opacos que será empleada para insertar personajes en movimiento en una escena nocturna.

Lo más frecuente es que las tres opciones (escenario real, efectos ópticos y escenarios reconstruidos en estudio) aparezcan mezcladas en un mismo film, sobre todo en los rodados a partir de 1943, pero hay excelentes ejemplos de estas técnicas mixtas en películas precedentes de su época inglesa, como Blackmail. En todo caso, esta manera de trabajar con las imágenes permite incrementar los valores sim-

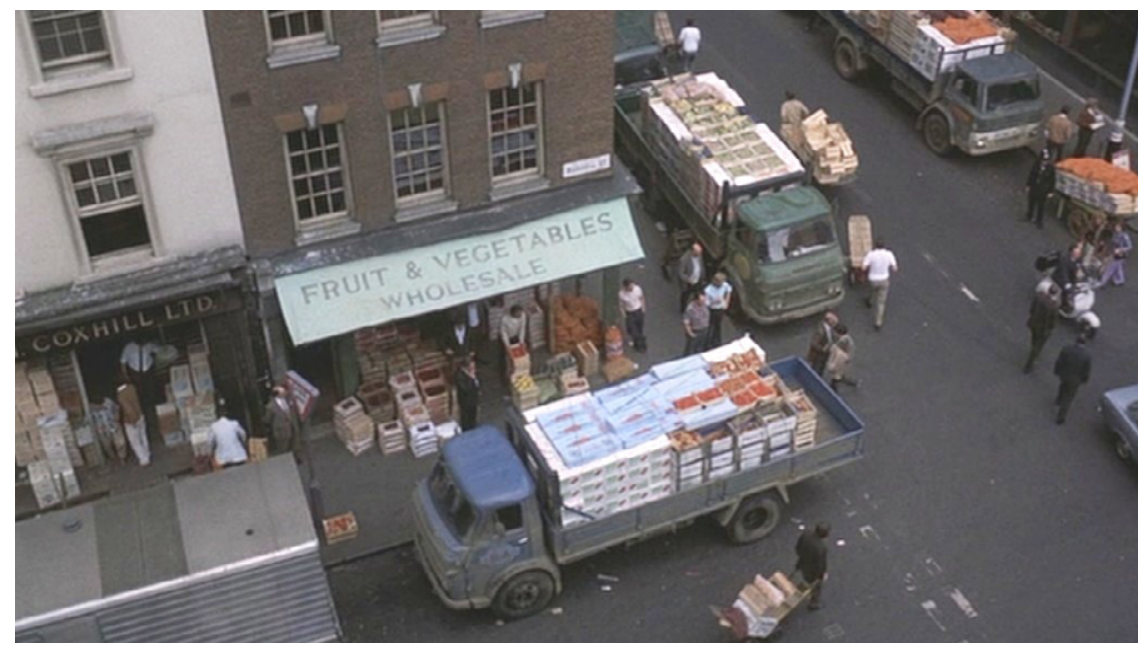

Figura 4. Plano rodado en escenario natural mediante una estética documental. Fuente: http:// galeon.com/whitlock/frenzy.html El desaparecido mercado del Covent Garden de Londres en Frenzy.

(21) McGILLIGAN, P. (2003), pág. 428

(22) McGILLIGAN, P. (2003), pág. 493.

(23) Como la playa de Copacabana (Rio do Janeiro) en sobreimpresión desde el apartamento de Ingrid Bergman en Notorious. 


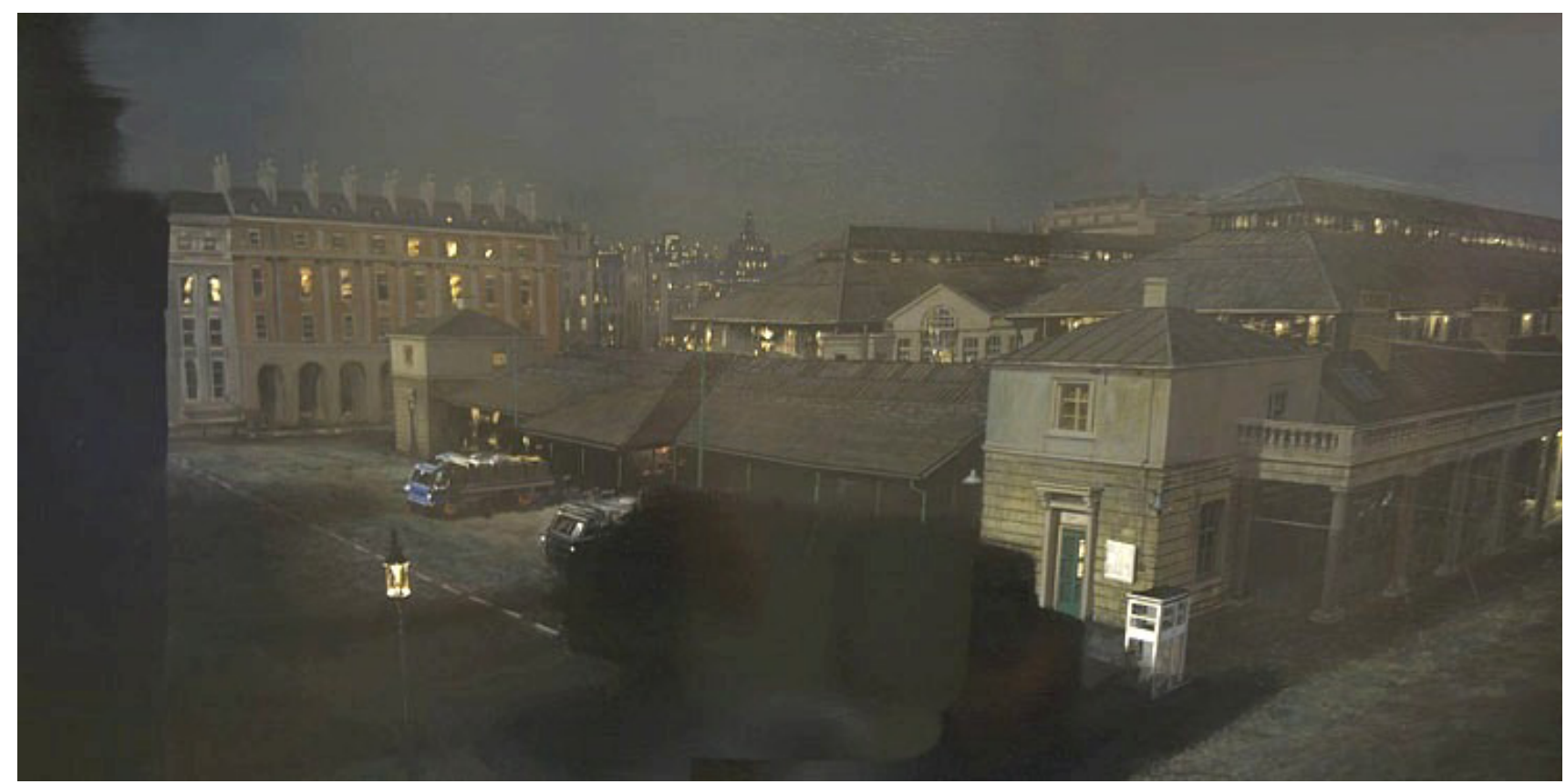

A FIGURA 5. El Covent Garden recreado mediante transparencias en Frenzy. Fuente: http://galeon.com/whitlock/frenzy.html La macha negra inferior es para insertar otra imagen mediante la técnica matte painting.

bólicos o emocionales del relato, facilitando al creador poner el acento en aspectos concretos del entorno ambiental, algo que un rodaje estricto en exteriores no posibilita.

La ciudad reconstruida en un set siempre fascinó a Hitchcock, amante de los grandes desafíos técnicos, como la reconstrucción en un estudio de un fragmento urbano. Me refiero al bloque de apartamentos que aparece en Rear Window, una película aparentemente localizada en el Greenwich Village de Nueva York. Nos situamos en treintaiún apartamentos de los que doce están totalmente amueblados, utilizados para recrear un auténtico microcosmos. El decorado sirve de contexto residencial para una historia con un tono que oscila entre lo trágico y lo humorístico, pero en todo caso poco condescendiente con una forma de vida en sociedad que aboca a la soledad, a la resignación $y$, en el peor de los casos, al homicidio.
La búsqueda de lugares emblemáticos siempre está presente en las películas de Hitchcock. Esta estrategia visual estimula la atención del espectador y está especialmente cuidada en los momentos cumbre, en los que la tensión narrativa precipita el final de los films. Un ejemplo señero: la lucha en la estatua de la Libertad en Saboteur, tal vez el mejor lugar que muera el quintacolumnista fascista que conspira contra el futuro de los Estados Unidos.

Esta capacidad para localizar escenas cumbre en lugares emblemáticos es una constante en Hitchcock, así esas secuencias se rodean de un aura especial que incide en la valoración inconsciente del espectador, que toma conciencia de la importancia de lo que está viendo. Estas imágenes no son un simple locus y su finalidad no es sólo la ubicación espacial.

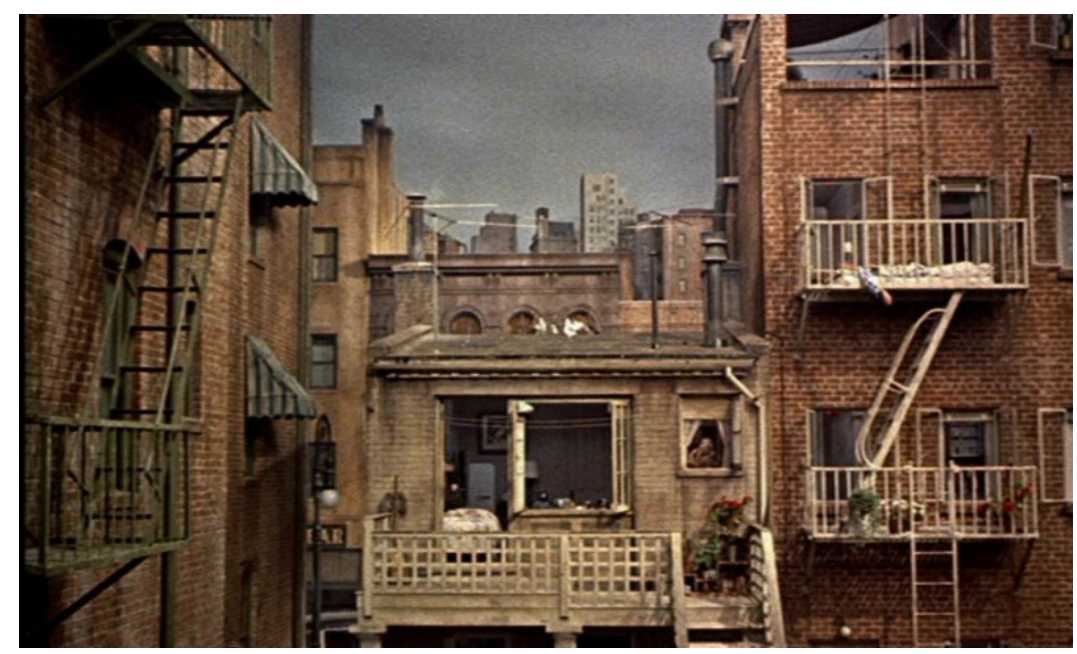

4 FiguRa 6. El patio trasero y el vecindario en Rear Window. Fuente: Paramount Pictures. Decorado de los apartamentos de Nueva York. La ciudad como enjambre humano. 


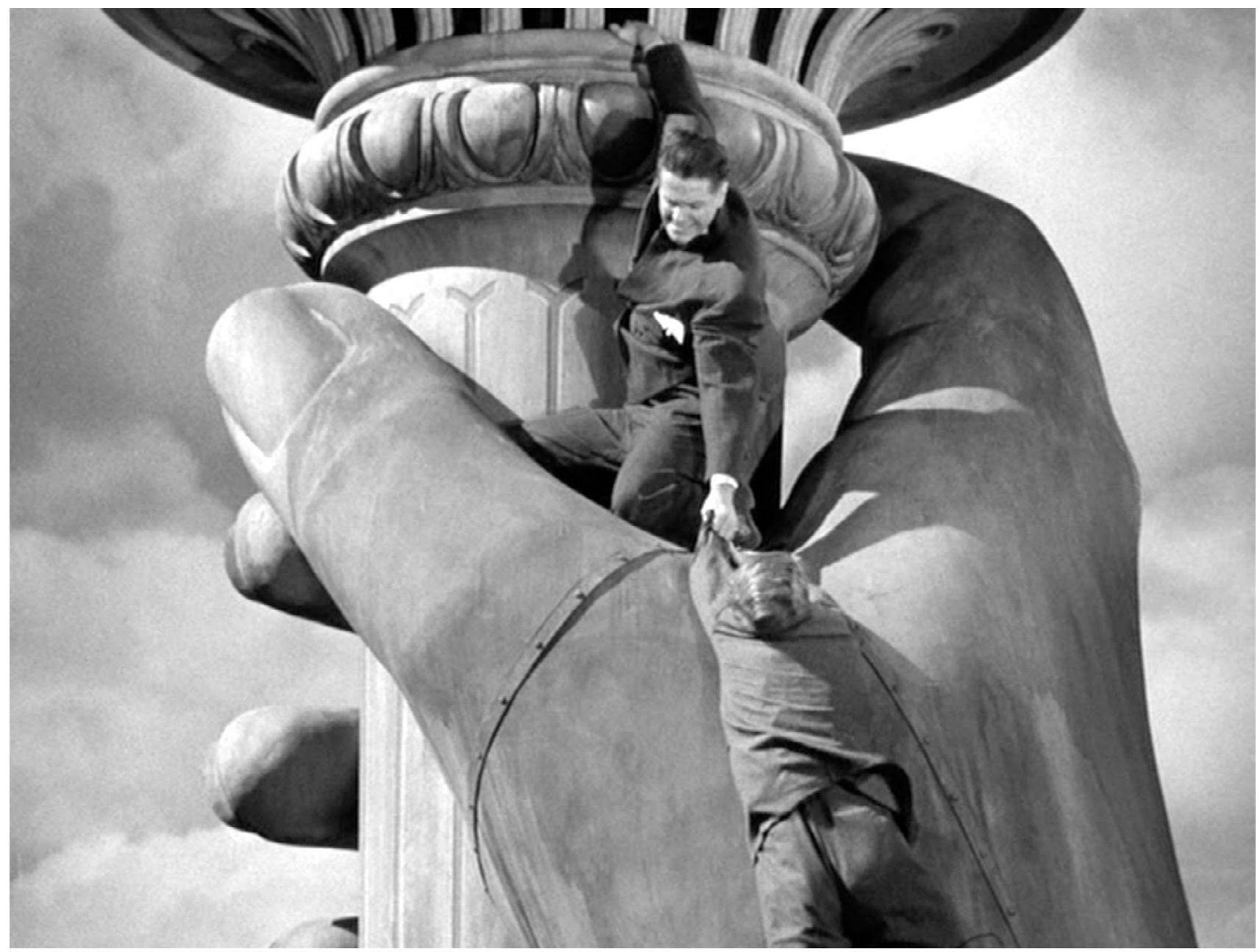

ム Figura 7. Escena final en la estatua de la libertad en Saboteur. Fuente: DVD, Universal Pictures.

En este sentido debe interpretarse la presencia de la cúpula del British Museum, escenario de la persecución final de Blackmail, de la centrica Traflagar Square, lugar del encuentro entre Silvia Sidney y el policía clandestino en Sabotage, o el Albert Hall de Londres, emplazamiento para el asesinato de un alto cargo político en las dos versiones de The Man Who Knew Too Much. En la versión de 1956 de este film, la vocación de Hitchcok por lo emblemático adquiere también una dimensión turistica, ya que emplea escenarios bien conocidos de origen marroquí visitados por los protagonistas a la sazón en viaje de placer. Me refiero a la gran plaza Jmaa el Fna de Marraquech, y al Hotel la Mamounia. Cuando el matrimonio protagonista regresa a Londres, los escenarios se hacen más anodinos y se traslada la acción a barrios más bien populares, concretamente aparece Camden Town. En esta localización (recreada en estudio) es donde está la capilla que da la clave a los protagonistas para descubrir el lugar en el que está secuestrado su hijo. Si en la tradición del relato gótico inglés el misterio y la trama policial nos remite a mansiones siniestras, bosques amenazante y páramos inhóspitos; en la citada película, son los escenarios urbanos (aunque sean lugares turísticos, edificios monumentales o barrios residenciales) los que nos ofrecen un ambiente no menos inquietante y desorientador. Es evidente que la visión de lo urbano recoge aquí una tradición de amplio recorrido literario y cinematográfico en la que se menosprecia la ciudad o, mejor dicho, se considera un ámbito inequivoco para localizar conflictos.

Los medios de transporte son otro elemento clave en la definición de lo urbano hitchcockiano, y están representados en sus diversas categorias a lo largo de toda la filmografia del director, ya sean los trenes de cercanías conocidos en América como commuters (Strangers on aTrain), el metro (por ejemplo en el cameo del propio director en Blackmail, figura 8), o las grandes estaciones que congregan cientos de viajeros, como la famosa Grand Central Station de Nueva York, lugar en el que Cary Grant consigue escapar de las amenazas urbanas en North by Northwest.

Un comentario sobre Topaz, la más internacional de las películas de Hitchcock, ya que se desarrolla en Copenhague, Nueva York, Paris, Washington, Weisbaden y La Habana. Siempre abierto a las novedades, aqui el realizador expone su visión sobre los escenarios urbanos actuales tendentes cada vez más a ser impersonales, así las localizaciones son 


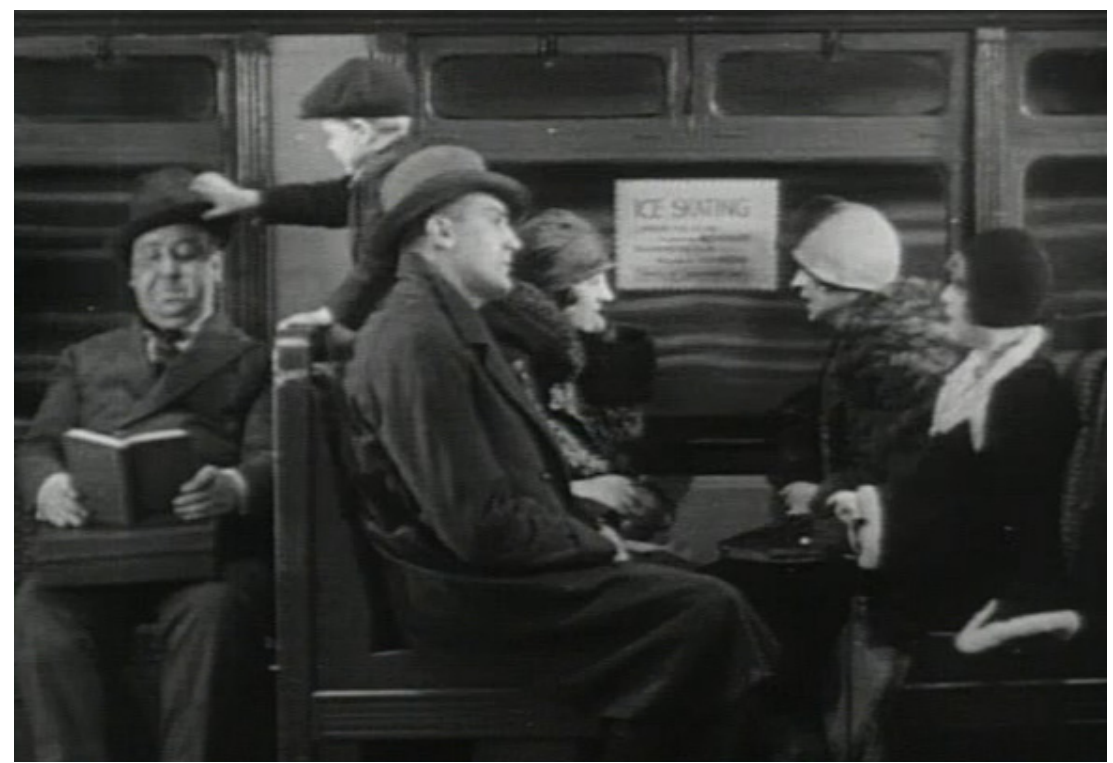

4 Figura 8. Hitchcock y los medios de transporte urbanos. Blackmail.

casi imposibles de ubicar, los personajes van de un país a otro sin encontrar hitos referenciales. Se presenta el mundo como un ecosistema homogéneo, de imágenes intercambiables y fácilmente comunicado de unos puntos a otros.

\subsection{La ciudad como escenario natural: The Shadow of a Doubt y I Confess}

Obsérvese la gran cantidad de personal y material técnico necesarios para una pequeña intervención en un escenario natural

Decididamente, los rodajes en escenarios naturales son minoritarios en el cine de Hitchcock, incluso las dos películas seleccionadas en este apartado combinan ampliamente localizaciones en exteriores y escenarios reconstruidos. La novedad en 1943 (The Shadow of a Doubt) es que se rodaron escenas en una casa real, algo poco frecuente en el Hollywood de aquellos años. Se eligió una vivienda unifamiliar rodeada de jardín, en una ciudad de amplios espacios abiertos y edificios de escasa altura. El entorno urbano ideal de lo que conocemos como suburbio en América, una forma de construir y de vivir en sociedad que ha sido exportada hacia Europa y a otras partes del mundo, con independencia de la existencia previa de experiencias similares de este tipo en el Viejo Mundo. Este mundo residencial se contrapone a los centros urbanos tradicionales, identificados con los edificios apiñados, el estrés de la aglomeración y las patologías derivadas de la vida en hábitat concentrados.

La novedad de rodar en escenarios reales se tradujo en numerosos problemas para el equipo técnico de la película (figura 10). Los cambios de iluminación en los días nublados obligaron a cambiar escenas diurnas por nocturnas, y las

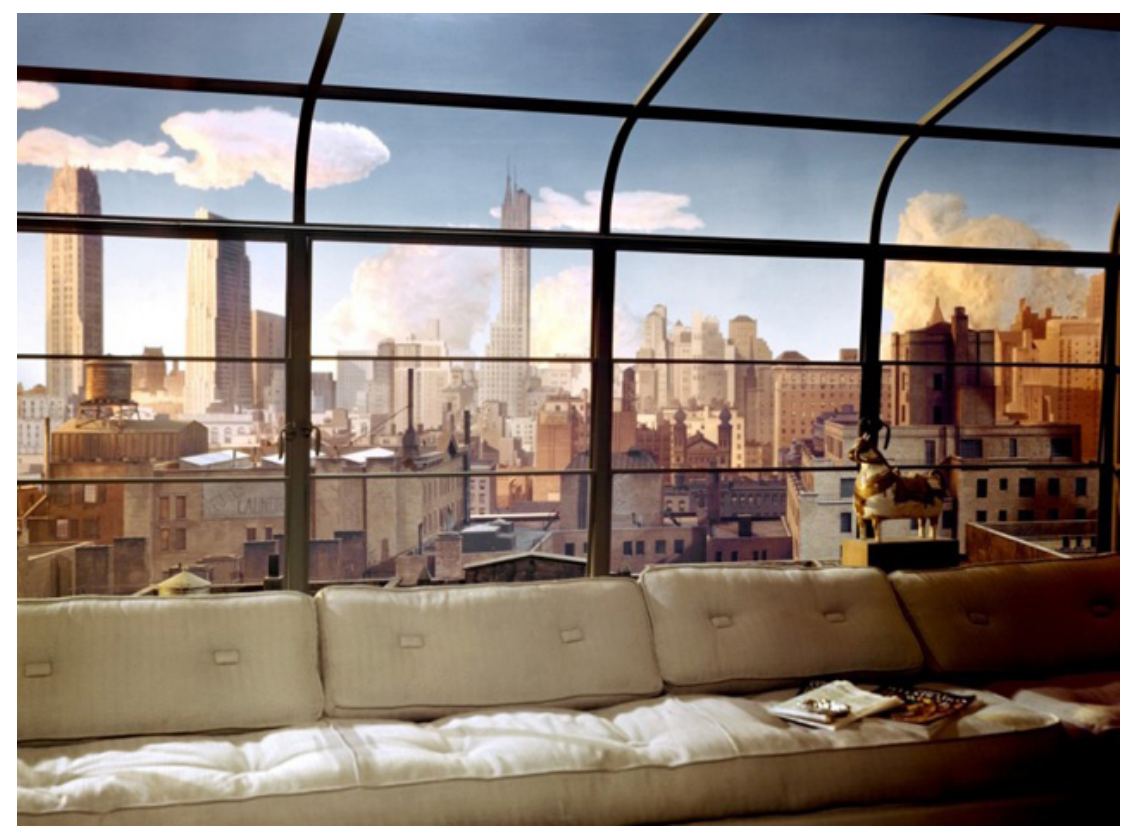

4 Figura 9. Ciclorama con el skyline de Nueva York en Rope. Fuente: DVD, Universal Pictures. Sinécdoque visual: un elemento (la línea de cielo) representa el todo (Nueva York). 


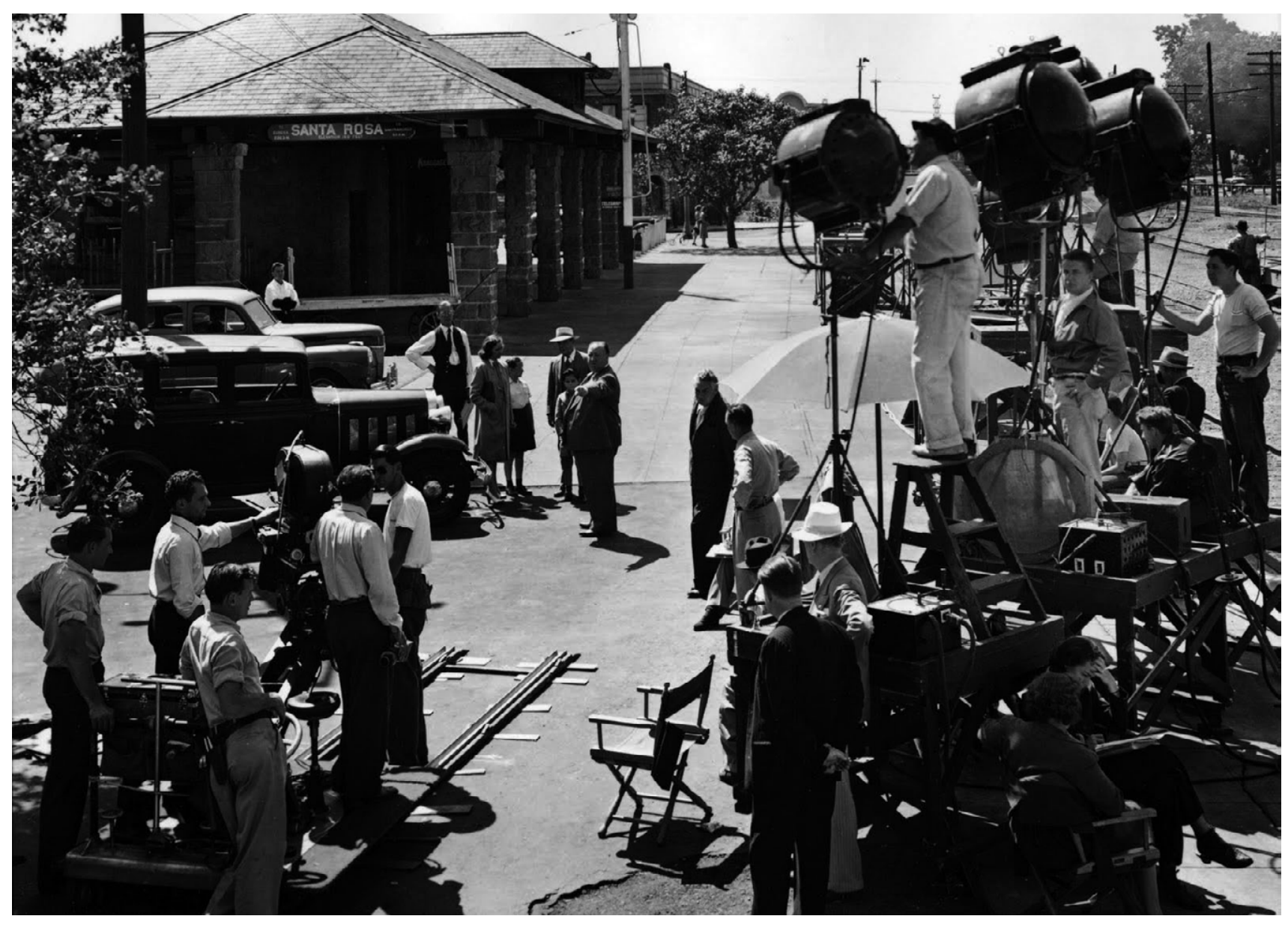

\ Figura 10. Rodaje en la estación de tren de Santa Rosa (California) para The Shadow of a Doubt. Fuente: DVD, Universal Pictures. Obsérvese la gran cantidad de personal y material técnico necesarios para una pequeña intervención en un escenario natural.

multitudes que perseguían al equipo de rodaje llevaron a tener que esperar a altas horas de la noche para poder cortar las calles y rodar con relativamente menos dificultades.

Para este primer encuentro entre Hitchcock y la realidad urbana de los años cuarenta se eligieron dos localizaciones antagónicas; las primeras escenas, con el protagonista "Uncle Charlie" dando esquinazo a los detectives y viviendo en una miserable pensión, se escogió la ciudad de Newark (New Jersey). El grueso de la producción se desarrolla sin embargo en Santa Rosa (California), que en los años cuarenta era una pequeña población de unos 13.000 habitantes y que como muchas urbes americanas tienen una estructura urbana ortogonal generada a partir de una plaza central. En aquellos años, el aspecto de Santa Rosa era bastante pintoresco y su fisonomía respondia al ideal de ciudad familiar similar al que aparecia en las pinturas de Norman Rockwell. Los cambios recientes del centro urbano de Santa Rosa han transformado su pasado "pintoresco", ahora la ciudad responde a unos esquemas de tipo homogéneo impuestos de manera generalizada (plazas duras, mobiliario urbano funcional de diseño postmoderno, peatonalizaciones al servicio del comercio) que no la diferencian de otras ciudades del resto del mundo (figura 16). Aunque algunos de los edificios que aparecian en la película se utilizan hoy como reclamo turístico, otros han sido demolidos, como por ejemplo la biblioteca pública.

La publicidad de la época no desaprovechó la ocasión para insistir que esta nueva forma de rodaje en exteriores "recuperaba la forma de rodar de los inicios del cine" ${ }^{24}$, un aspecto, aunque no el único, que hacen de este film uno de los favoritos de su director ${ }^{25}$. Hitchcock adoraba Santa Rosa, primero porque se encontraba cerca de su hogar californiano, y segundo, porque representaba una serie de ideales (privacidad, independencia, contacto con la naturaleza, individualismo, empatía con los vecinos) relacionados con las nuevas formas residenciales suburbanas que se estaban desarrollando en la costa oeste norteamericana. Santa Rosa era un urbanismo diferente, opuesto al que se identifica

(24) McGILLIGAN, P. (2003), pág. 292.

(25) Asi al menos se lo expresaba a François Truffaut en las entrevistas recogidas en: TRUFFAUT, F. (2010). 
con los centros urbanos degradados de la costa este, que en la película se identificaban con Newark: lugar de origen del asesino que busca refugio en la vivienda de sus familiares californianos. Hitchcock en esta ocasión recoge una tradición de desprecio de la vida urbana, o más bien a una determinada forma de vida urbana, ligada a los centros urbanos congestionados y con construcciones en altura, unos escenarios que darían mucho juego a la tradición del cine y la novela negras. Este antiurbanismo, que en cierto modo es retórico, se contrapesaba no con la vida idealizada en el mundo rural (algo tradicional en el cine americano), sino con las formas de vida de la ciudad media americana, germen de las actuales periferias urbanas. No es tanto un "menosprecio de corte y alabanza de aldea", sino más bien un "menosprecio de ciudad compacta y alabanza de viviendas unifamiliares en la periferia".

Hitchcock no vuelve a recurrir de manera amplia a los escenarios urbanos naturales hasta 1952. Dentro de una trama de culpabilidades y problemas de conciencia, Yo confieso se centra en el personaje de un sacerdote, perseguido por la culpa de una relación sexual ilícita (un tema atenuado en la versión final) y por el compromiso del secreto de confesión. Para desarrollar estos aspectos argumentales era preciso un entorno urbano identificable con el catolicismo, las localizaciones que se ajustaban a este propósito las encontró en la ciudad francófona de Quebec. Los intereses ideológicos son evidentemente diferentes a los de la película antes comentada.

Inesperadamente, es esta una de las películas de Hitchcock con mayor presencia de la ciudad, se suceden planos de edificios notables del casco histórico y también sus peculiares calles estrechas; en algunos momentos, la sucesión de vistas urbanas nos acerca al cine documental, casi como digresiones en torno a la trama. De manera distinta a otras ocasiones, la ciudad ya no es un escenario inhóspito que marca acontecimientos existenciales extremos, como el asesinato, se presenta en esta ocasión la ciudad como un "objeto bello". Un bien digno de admiración, un entorno que puede fascinar a los personajes y al espectador, estamos ante el antecedente de una práctica visual que dará sus mejores resultados en Vertigo. Habria que estudiar en profundidad si esta fascinación no está envuelta en una noción cristiana de pecado, sobre todo cuando se identifica en este proceso ciudad y mujer. Unas ciudades visualmente bellas, relacionadas siempre con caracteres femeninos, que parecen dispuestas a servir de tentación. Desde una perspectiva más práctica, también se puede entender esta presentación visual como una forma de mercadotecnia urbana, destinada a la promoción turística de las ciudades elegidas como escenario del film, Quebec en un caso y San Francisco en otro. No olvidemos tampoco que Hitchcock inicia To Catch a Thief en una agencia de viajes, o que para ambientar la huida de los disidentes políticos de Topaz utiliza la excusa de una visita turística a una fábrica de porcelanas. En todo caso, imágenes de una gran riqueza polisémica gracias a las diversas interpretaciones que sugieren.

La mayoría de los escenarios naturales utilizados en $Y_{0}$ confieso se corresponden con el centro de Quebec, que dio al director todas las facilidades para realizar su trabajo. El parlamento, el ayuntamiento y el Tribunal de Justicia se reconocen fácilmente en la película, así como la iglesia de Saint-Zéphirin-de-Stadacona, fundamental en la trama del film ${ }^{26}$.

Lo interesante de este film es que los conflictos de conciencia se visualizan mediante metáforas que resultan de contraponer en un mismo plano un personaje y un monu-

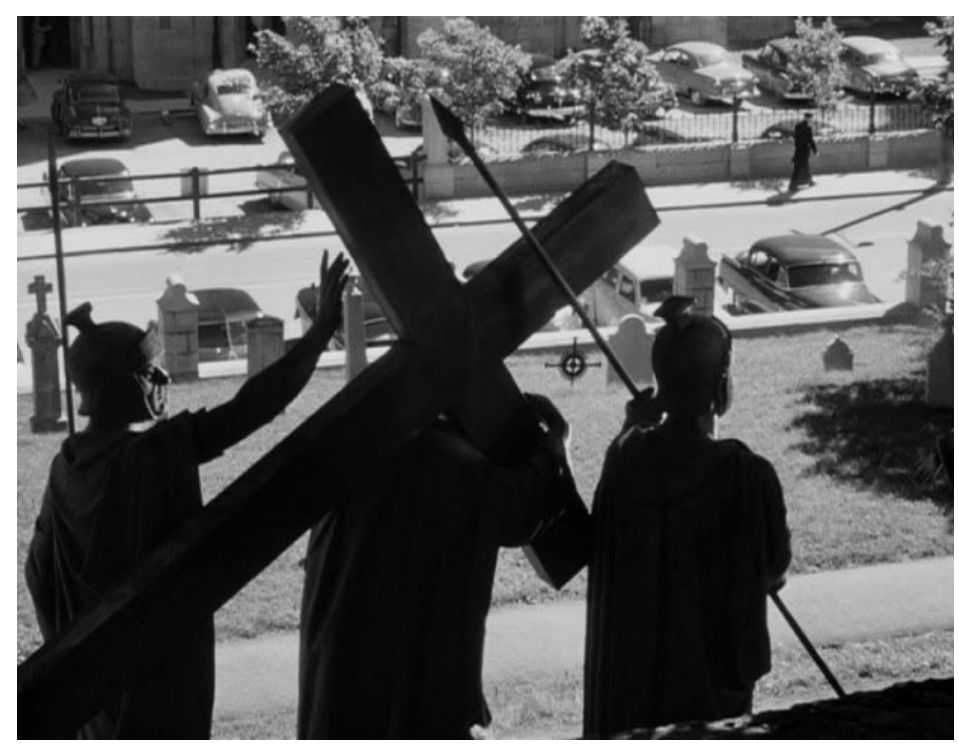

A Figura 11. Quebec City una ciudad con iconografía católica en I Confess. Fuente: DVD, Warner Bros.

(26) McGILLIGAN, P. (2003), pág. 427. 
mento urbano. Por ejemplo, en la figura 11, en profundidad de campo aparece el protagonista, agobiado por sus problemas, y en primer término se impone una estatua de Cristo llevando la cruz a cuestas, como imagen del via crucis. El símil es claro y sencillo, comprensible para todo tipo de audiencias que conozcan la iconografía católica.

En otras escenas se buscan impactos visuales efectistas, de un valor icónico más abstracto, como las calles escalonadas del centro histórico de Quebec que son el marco excepcional para ubicar uno de los habituales cameos del director (figura 12).

Estas escaleras sustituyeron en la trama urbana unas antiguas escaleras del siglo XVIII que conectaban el desnivel existente entre la ciudad alta y la ciudad bajas del viejo Quebec.

\subsection{Una trilogía sobre la pérdida de la identidad: Vertigo, North by Northwest $y$ Psycho}

Entre 1958 y 1960 Hitchcock rueda tres películas que son la cumbre de su carrera. A pesar de sus diferencias argumentales, se puede decir que tienen un tema en común: la pérdida de identidad de los protagonistas, provocada por una obsesión amorosa (Vertigo), un complot de espionaje internacional (North by Northwest) o un trastorno psicopatológico (Psycho). Se pueden considerar trasuntos sobre la moderna alienación en sociedades avanzadas, reflejos de seres humanos pedidos en la maraña de la existencia, disfrazando una visión existencial de la experiencia humana muy oscura bajo las estructuras del melodrama de intriga, la comedia de espías o el género del terror respectivamente.

En este apartado, solo se darán unas pinceladas sobre la presencia de la ciudad en estas tres películas, tan ricas semánticamente, dejando abierta la propuesta a futuras interpretaciones más detalladas.
Empezaré por la más reciente en el tiempo. No podemos olvidar que el atrevido ambiente sexual del comienzo de Psycho, en el que los amantes se citan de manera clandestina a la hora del almuerzo, se contextualiza con un plano aéreo de la ciudad de Phoenix. La escena es una sucesión de planos panorámicos encadenados filmados a la dura luz del mediodía y nos ofrecen la línea de cielo de la capital de Arizona. La intención es muy distinta a la sinécdoque de Rope (figura 9), aquí la ciudad no es un telón de fondo, es la clave que condiciona la situación existencial de los protagonistas. Después de este inicio, no puede sorprendernos que el personaje de Janet Leight huya de la ciudad con un botín robado, que tal vez pueda mejorar su complicada situación sentimental. Volvamos al plano inicial de la película, después de ver la ciudad a vista de pájaro, la cámara nos introduce a través de una ventana en la habitación en que una pareja descansa tras una relación íntima. La sensación de hastío, el calor del desierto y la mirada casi indecente que sentimos como espectadores nos sitúan en un ambiente ya conocido, el mismo que reflejó Edward Hopper en sus cuadros ambientados en el interior de habitaciones de hotel. Deshumanización y soledad de unos individuos solo comprensible desde la dura realidad urbana contemporánea; así, el contexto de la ciudad dado por la panorámica y la presencia de los personajes en la cama son una misma realidad interdependiente. Una imagen de carácter general explica una situación individual.

North by Northwest es otro capitulo en el análisis de la pérdida de identidad en el mundo moderno, esta vez en clave de comedia. El discurso visual de esta película memorable tiene interesantes referencias a artistas modernos, sobre todo a las propuestas relativas a urbanismo de Frank Lloyd Wright.

Un cuadro de Paul Klee, artista del que Hitchcock tenía obras en su colección privada, tiene una curiosa presencia en la película. Me refiero a "Calle principal y calles laterales", conservado en el Wallruf Richartz Museum de Colonia. En

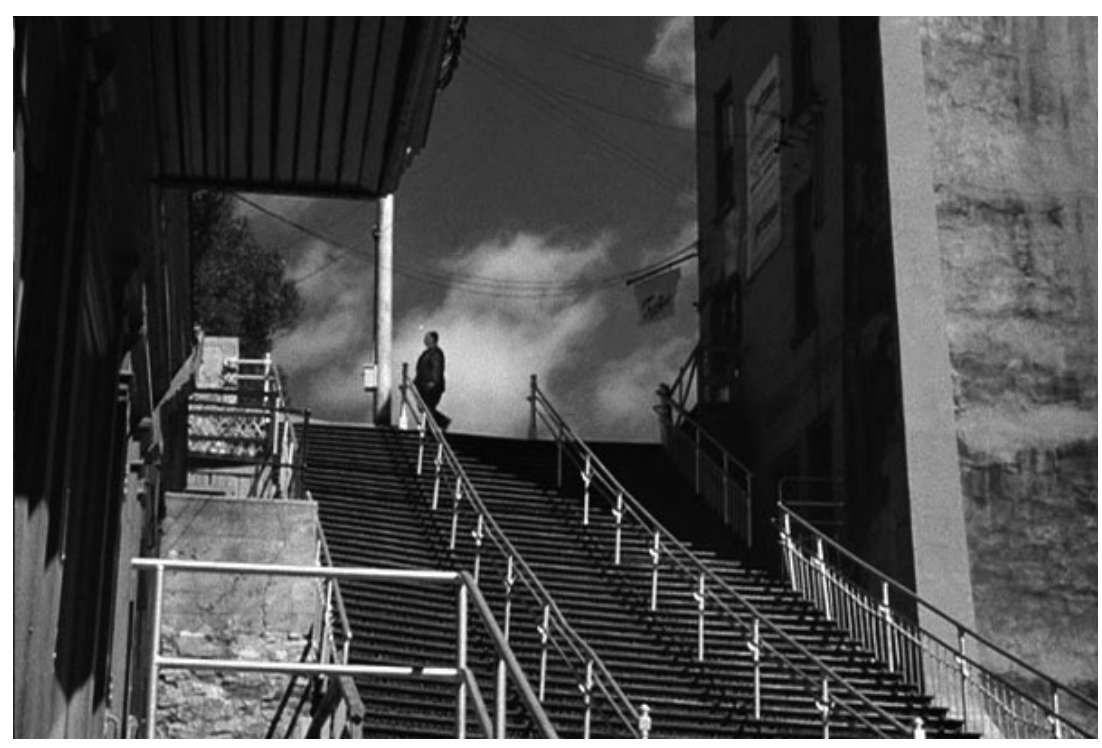

Figura 12. L'Escalier Casse Cou. Fuente: DVD, Warner Bros. 


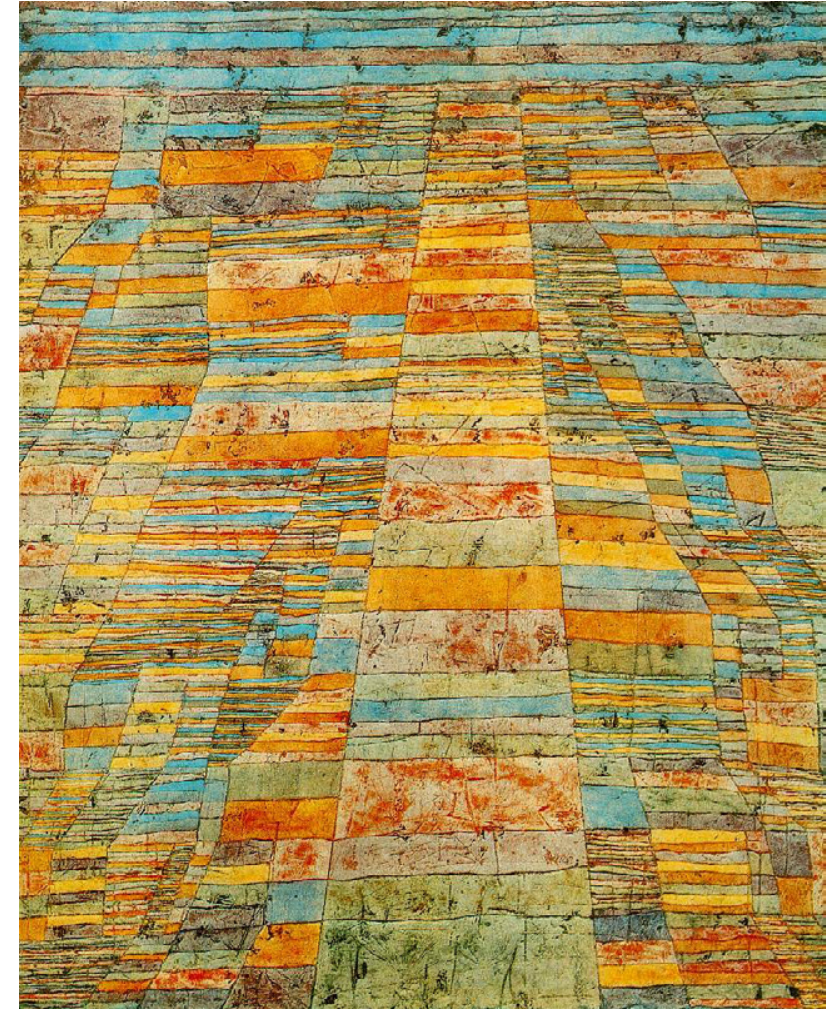

ム FiguRA 13. Calle principal y calles laterales de Paul Klee.

esta pintura, la perspectiva (ajena a las norma de Renacimiento) es aparentemente segura en el trazado de sus líneas, pero las supuestas calles secundarias son tan inseguras como la principal, más parece un laberinto, ya que los caminos no llevan a un punto de partida, sino que se pierden. Ante el espectador lo que se está planteando es un problema de orientación, que cada uno resolverá a su manera, y que por tanto nunca tendrá una resolución unívoca, si eso fuera así dejaría de ser un problema ${ }^{27}$. El cuadro es un trasunto de la vida cotidiana, y al mismo tiempo, sirve para entender las encrucijadas planteadas por Hitchcock. Las situaciones argumentales de sus películas están claramente expuestas, pero no se sabe a dónde conducen ni qué desvíos perversos pueden presentar. Los personajes hitchcockianos, como la mayoría de los habitantes de las ciudades, quedan a la deriva del destino y en un entorno arquitectónico cuya dureza parece acompasar las situaciones de desasosiego, como el cuadro de Klee.

El plano de la figura 14, realizado con la técnica de vidrios coloreados y diseñado por A. Whitlock, presenta una vista del edificio de las Naciones Unidas, emblema de Nueva York, y aparece justo en el momento en que la identidad personal del protagonista queda totalmente alterada al producirse un asesinato en el mismo edificio.

Ya en los títulos de crédito de North by Northwest (creados por Saul Bass) se incidía en el mencionado carácter laberíntico de la ciudad moderna, ortogonal en sus formas pero frenética para sus habitantes. La imagen de Klee persigue a Hitchcock y a sus colaboradores, ¿la misma imagen del citado cuadro no parece ser también la base del plano de I Confess en que se ven la escaleras de la ciudad de Quebec en la figura 12 ?

Pero los títulos de crédito de North by Northwest son también una sintesis de casi todos los elementos que definen lo urbano, siempre desde el punto de vista de la cultura popular. Aparecen aquí un conjunto de imágenes que a fuerza de repetirse se han convertido en iconos de lo que no pueden faltar en una ciudad moderna, presentados aquí con un curioso tono irónico ${ }^{28}$. La percepción del espectador de cine se define por modular una fisonomía vaga e indistinta de lo que es una ciudad moderna, un entorno funcionalista

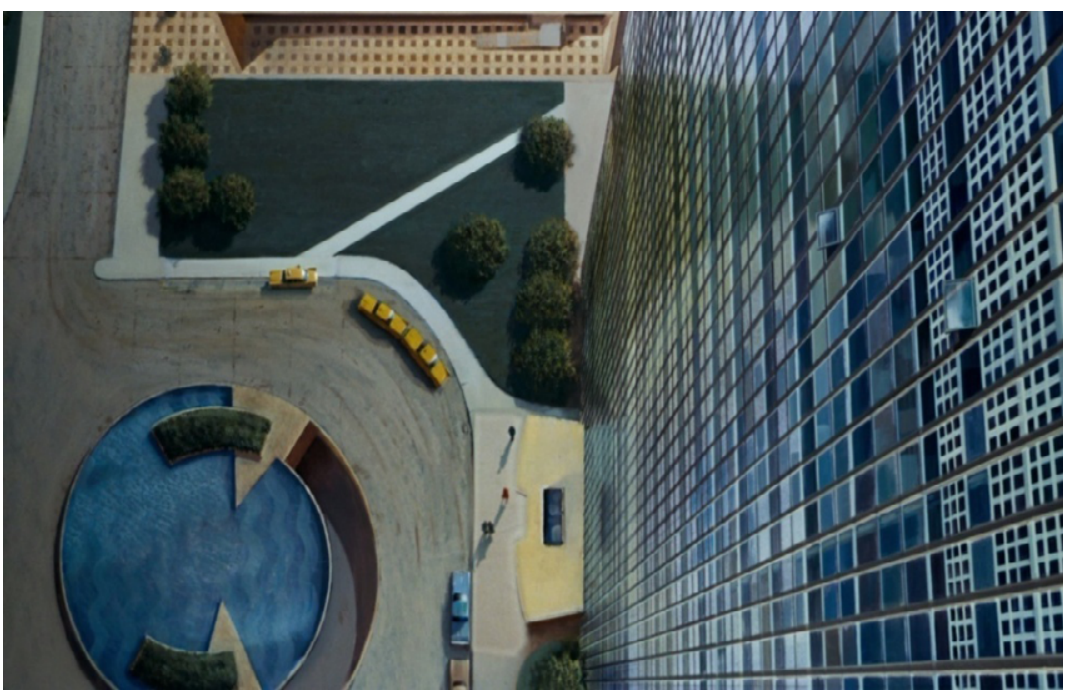

FiguRa 14. Plano pintado por Albert Whitlock para North by Northwest. Fuente: DVD, Universal Pictures.

${ }^{(27)}$ Esta reflexión procede de: ARGAN, Giulio Carlo (1984). El arte modeno, Fernando Torres, Valencia, pág.143.

${ }^{(28)}$ En el plano final de los títulos de la película, el propio Hitchcock en uno de sus cameos más famosos pierde el autobús. 


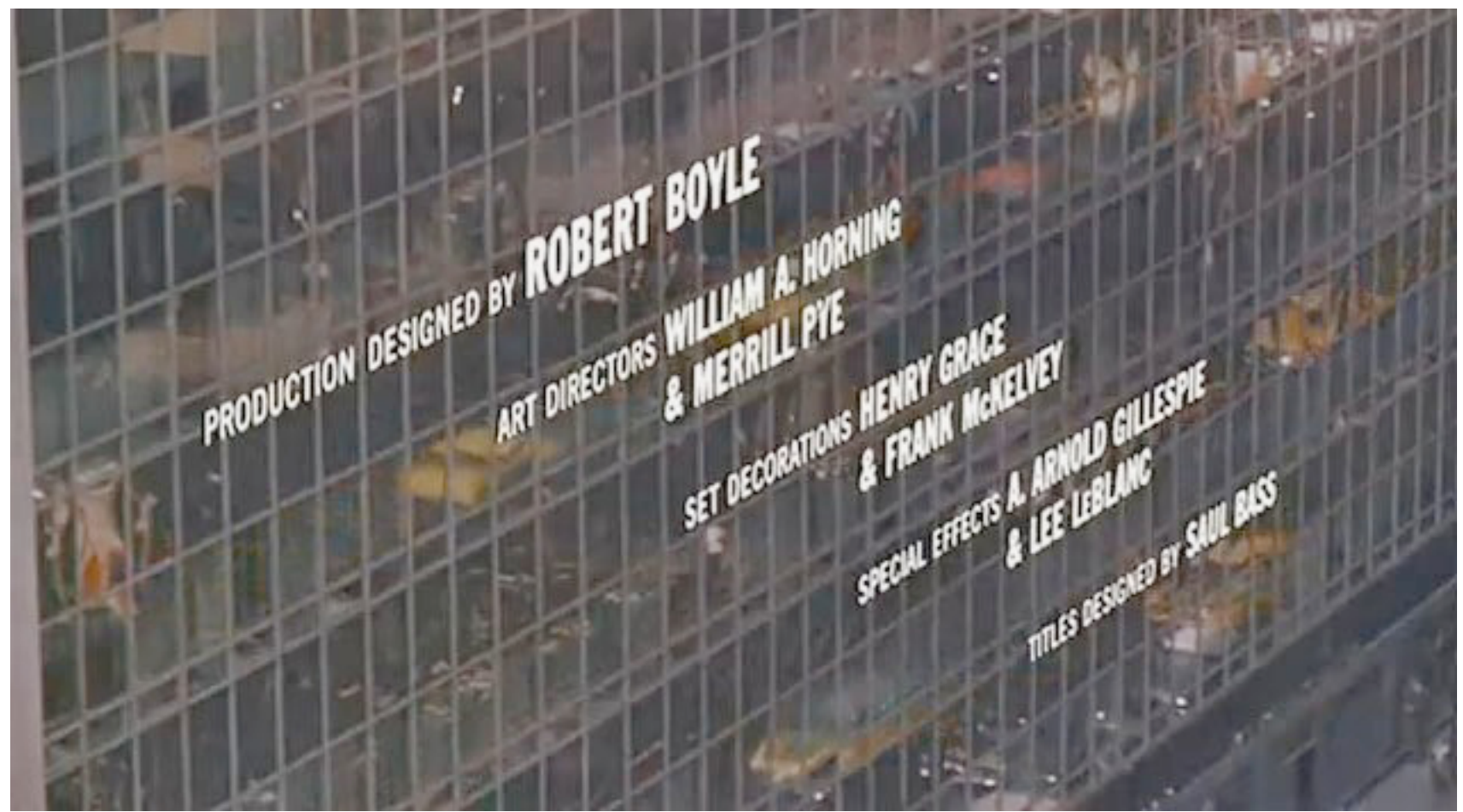

\ FiguRA 15. Títulos de crédito diseñados por Saul Bass para North by Northwest. Fuente: DVD, Universal Pictures.

en el que no pueden faltar: los grandes puntos de llegada y salida de viajeros, las vías de comunicación saturadas de vehículos, los rascacielos, las luces artificiales que convierten la noche en día y, sobre todo, el dinamismo y el frenesí de las masas de gente que van y vienen ${ }^{29}$.

En North by Northwest vemos también como se repite la tendencia a presentar edificios emblemáticos que orientan al espectador en su viaje por la ciudad de los rascacielos: el hotel Plaza, Grand Central Station, las Naciones Unidas, etc. Inesperadamente, se incorpora al grupo una mansión de la zona residencial privilegiada de la periferia neoyorquina: Old Westbury Gardens, una vivienda envidiable situada en Long Island. El aura que logró este edificio gracias a Hitchcock ha llevado a que reaparezca en otras películas posteriores como Love Story, Cruel Intentions y Wolf. Pero el elemento clave para el discurso urbanístico de la película se reserva para la escena final, me refiero a la casa futurista Vandamme. Una reconstrucción en estudio que recoge el espíritu arquitectónico de Frank Lloyd Wright, influencia clave en la configuración estético y espacial del cine de Hitchcock.

Figura central del Movimiento Moderno, Frank Lloyd Wright es el prototipo de los intelectuales que postulan contra la moderna forma de vida urbana. Su ideología a favor de una nueva forma de ciudad extensa no se puede separar de la realidad norteamericana. Para el arquitecto de Chi- cago "la ciudad, tal como la conocemos actualmente, va a morir" ${ }^{\prime 3}$. Expresaba así casi más un deseo personal en tono profético que una realidad tangible de su época, incluso llegaba a defender que los actuales "adelantos técnicos hacen innecesaria la concentración urbana, entendida ésta como necesidad de contacto, reunión, intercambio, etc." ${ }^{31}$. Definiendo la época actual como la era del maquinismo, Wright asegura que es este maquinismo el que destruirá la ciudad moderna. Y sin embargo esto no se considera una catástrofe, sino que se valora como una solución a los problemas de las urbes actuales, las cuales se definen como congestionadas, sin valores estéticos, con servidumbre hacia los rascacielos, con pocos espacios vivibles, sin estilo propio y proclives al derroche tanto económico como energético. La solución propuesta es la vuelta a una nueva vida rural; es decir, casas unifamiliares rodeadas de grandes porciones de terreno, aptos para producir parte del consumo familiar. Wright va más allá, ya que considera que las actuales redes de autopistas, los servicios de transporte, las redes de telecomunicaciones (con la amplia difusión de los contactos mediante el teléfono y de las imágenes gracias a la televisión) y las estaciones de servicio y gasolineras deberian convertirse en los ejes de la futura actividad comercial, social, económica y cultural. Esta nueva realidad urbana redimirá al hombre de los males de la ciudad moderna. La misma maquinaría que

$\left.{ }^{29}\right)$ Hemos constatado que todos estos elementos coinciden con la enumeración de los elementos que caracterizan las ciudades en el cine americano de los años veinte y treinta presentado por: GANDINI, L. (1994), pág. 10.

(30) WRIGHT, F. L. (1978), p. 142. La obra original es de 1953

(31) WRIGHT, F. L. (1978), p. 156. 

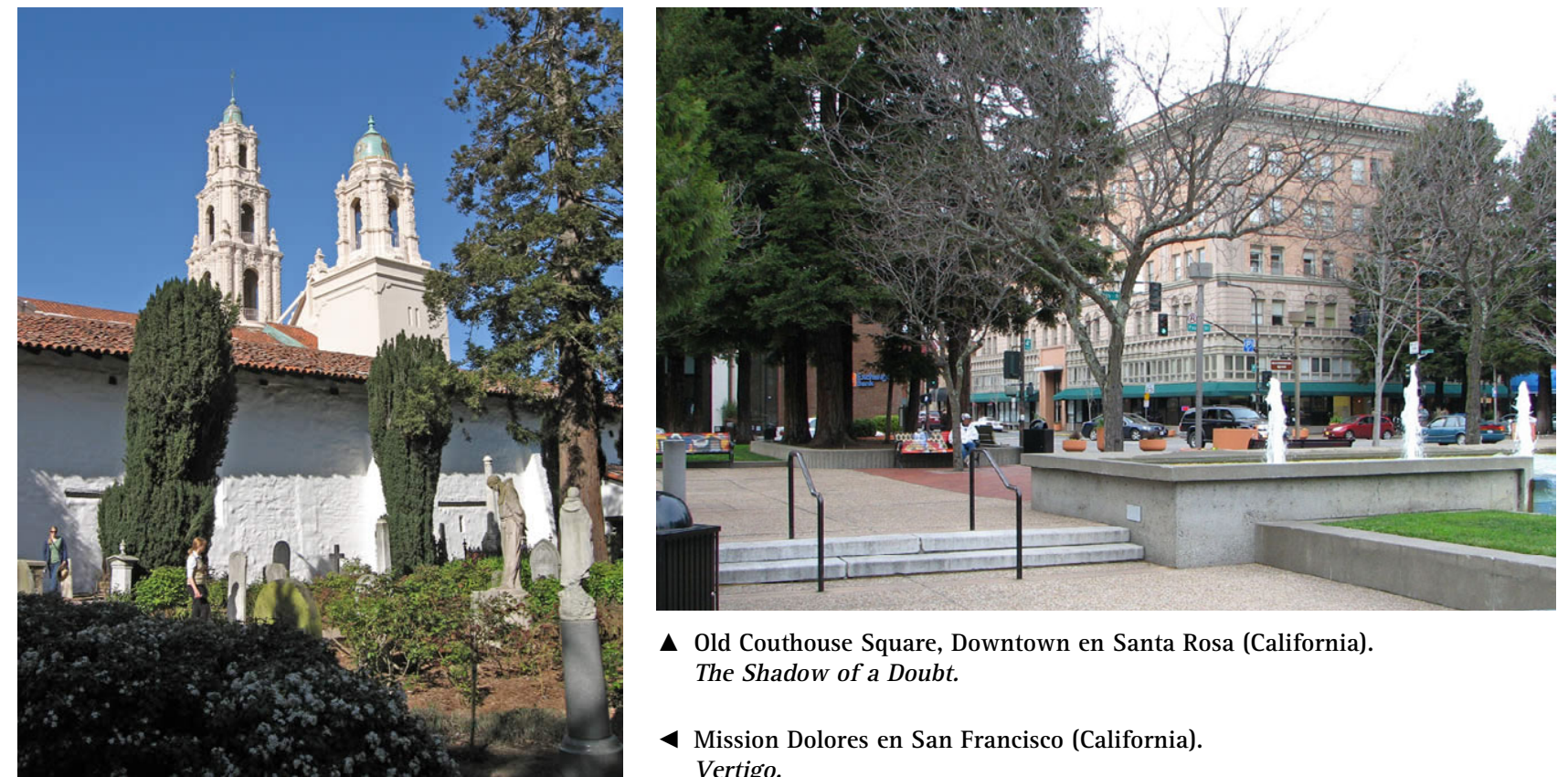

$\Delta$ Old Couthouse Square, Downtown en Santa Rosa (California). The Shadow of a Doubt.

4 Mission Dolores en San Francisco (California). Vertigo.

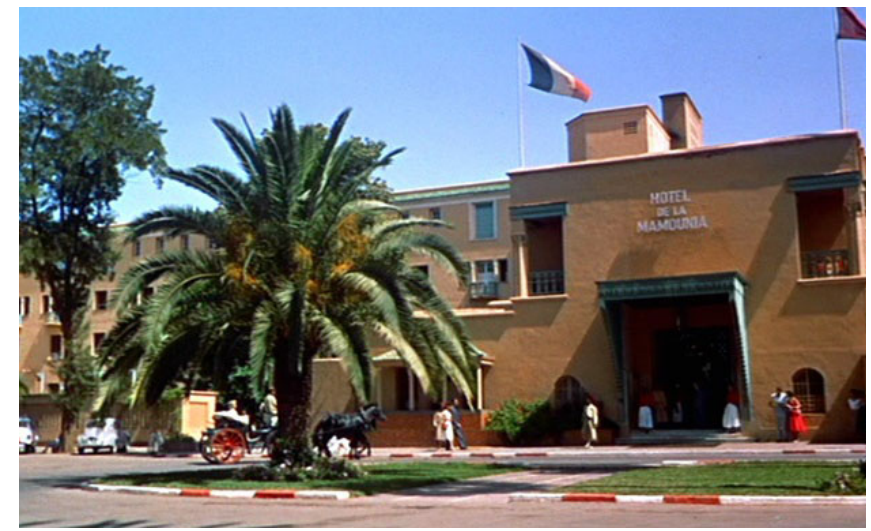

A Hotel La Mamounia en Marraquech (Marruecos).

The Man Who Knew Too Much.

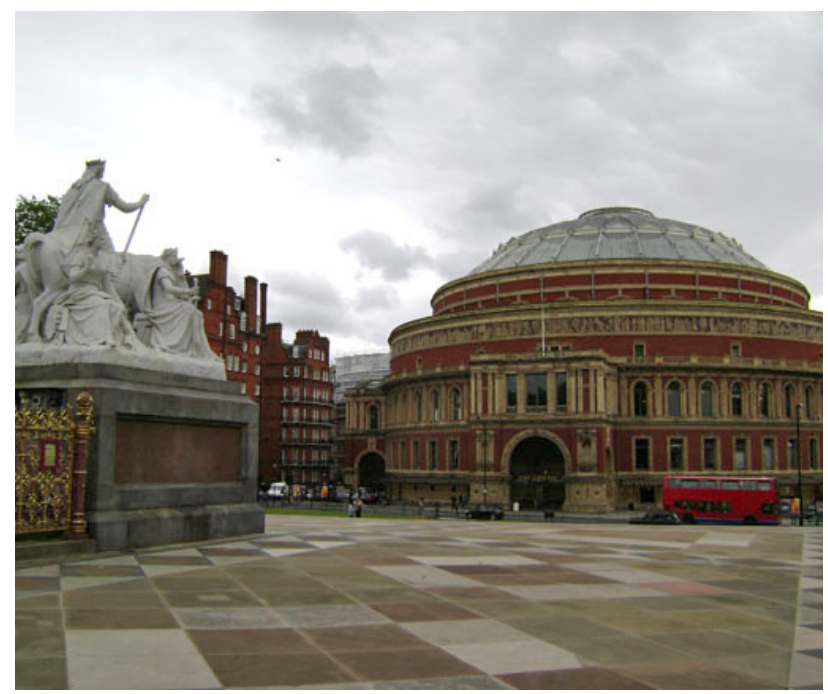

Royal Albert Hall en Londres (Reino Unido). The Man Who Knew Too Much.

FIGURA 16. Cine de Hitchcock, ciudad y turismo.

destruye las ciudades se ve, en fin, como la solución de los problemas. Desde la perspectiva actual, la visión futurista anti-urbana de Wright creo que no se ha impuesto a los modelos de ciudad preexistentes, sino que se ha superpuesto, a lo que han contribuido la proliferación de autopistas, las nuevas redes de comunicación, Internet, etc.

Esta realidad es ambivalente, pues por un lado hace más cómoda la vida cotidiana, pero por otro lado establece una serie de servidumbres que contribuyen a una alienación generalizada. Pero este debate tal vez se deba desarrollar en otro contexto.

La tercera referencia de la trilogía comentada es Vertigo. Resumen y culminación de muchos de los aspectos que hemos estado comentando hasta ahora, auténtico documental sobre las calles de San Francisco. Tan detallado es el recorrido realizado a lo largo y ancho de la ciudad

${ }^{(32}$ Se puede consultar al respecto la web: http://www.toursanfranciscobay.com/tours/hitchcocks-vertigo.html

${ }^{(33)}$ El Golden Gate tiene una presencia simbólica muy fuerte en la película, es el escenario del intento de suicidio de la protagonista, en este sentido ejerce una fascinación doble: la atracción derivada de la belleza del escenario natural y su posible lugar de tránsito para acceder al reino de la muerte.

(34) En este sentido, llama la atención las webs dedicadas a la localización geográfica de los escenarios de rodaje de películas de impacto popular, una fuente indudable para el desarrollo de este nuevo turismo de paisajes cinematográficos. Un ejemplo: http://www.movie-locations.com/ index.html 
californiana, y tan amplio el impacto a nivel popular de la película desde 1958 hasta hoy, que ha dejado huella en las prácticas actuales del turismo urbano. En efecto, la empresa "A Friend in Town"32 organiza visitas guiadas que comienzan en Silicon Valley y recorren Mission Dolores, el Palacio de la Legión de Honor, el Golden Gate (figura 1) ${ }^{33}$, el Museo de Bellas Artes y otros enclaves singularizados por aparecen en el film. Este dato nos muestra la diversificación de determinadas estrategias empresariales, pioneras en detectar como el imaginario colectivo, activado por las películas, pone en valor lugares, pasiajes y monumentos que puden ser objeto de una novedosa explotación turística ${ }^{34}$. Parece ser que esta tendencia se detecta con otras películas y otros lugares, marcando una nueva tendencia de mercadotecnia urbana que une cine, turismo y paisajes (figura 16). Curiosamente, la imagen de la ciudad se ve sometida a un "movimiento de ida y vuelta"; de la realidad a la pantalla y de esta otra vez a la realidad en forma de producto turistico.

\section{CONCLUSIONES}

Como ha señalado Gilles Deleuze, Hitchcock no concibe un film en función de dos términos: el realizador y la película, "sino de tres: el realizados, la película y el público que debe entrar en ella, o cuyas reacciones deben hacerse parte integrante del film" ${ }^{35}$. Tal vez, esto explica el impacto popular de sus films y su alta valoración por la mayoria de los estudiosos del cine. Por eso he seleccionado a este director, para establecer unas posibles pautas en relación a la influencia de lo audiovisual en nuestra percepción de la ciudad.

El impacto del cine en la manera que tenemos de percibir la ciudad se pone de manifiesto al menos en tendencias recientes que reclaman las localizaciones cinematográficas como recurso de explotación turística.

Las ciudades en el cine de Hitchcock se entienden en primer lugar como un valor referencial que condiciona la narración, pero en posteriores lecturas de los significados fílmicos se van incorporando valores simbólicos, que crean un discurso a menudo ambivalente sobre la vida urbana.

Las imágenes cinematográficas de Hitchcock se han puesto en relación con obras pictóricas de artistas que formaban parte de la colección privada del director, para así descubrir nuevos valores semánticos de las películas.

La relación del cineasta con la ciudad es ambivalente, ya que unas veces nos muestra una evidente fascinación con la urbe moderna, repleta de referentes emblemáticos, mientras en otros casos no duda en estigmatizar la ciudad tradicional compacta (centros urbanos tradicionales) y apostar por modelos de urbanismo más extensivos (periferias urbanas).

\section{Anexo 1. Películas de Hitchcock mencionadas en el texto}

- 1929 - Blackmail (La muchacha de Londres)

- 1934 - The Man Who Knew Too Much (El hombre que sabía demasiado)

- 1936 - Sabotage (Sabotaje)

- 1942 - Saboteur (Sabotaje)

- 1943 - Shadow of a Doubt (La sombra de una duda)

- 1946 - Notorius (Encadenados)

- 1948 - Rope (La soga)

- 1951 - Strangers on a Train (Extraños en un tren)

- 1953 - I Confess (Yo confieso)

- 1954 - Rear Window (La ventana indiscreta)

- 1955 - To Catch a Thief (Atrapa a un ladrón)

- 1956 - The Man Who Knew Too Much (El hombre que sabía demasiado)

- 1956 - The Wrong Man (Falso culpable)

- 1958 - Vertigo (Vértigo / De entre los muertos)

- 1959 - North by Northwest (Con la muerte en los talones)

- 1960 - Psycho (Psicosis)

- 1969 - Topaz (Topaz)

- 1972 - Frenzy (Frenesí)

- 1975 - Family Plot (La trama) 


\section{BIBLIOGRAFÍA}

ARGAN, G.C. (1984). El arte moderno, Valencia, Fernando Torres.

Belmans, J. (1977). La ville dans le cinéma de Fritz Lang à Alain Resnais, Bruselas, A. de Boeck.

BuRCH, N. (1987). El tragaluz del infinito, Madrid, Cátedra.

Cosgrove, D. (2002). "Observando la naturaleza: el paisaje y el sentido europeo del paisaje". Boletín de la Asociación de Geógrafos Españoles, 34, pp. 63-89.

COSTA MAS, J. (2003). "Visiones de la ciudad funcional europea y la ciudad blindada norteamericana en el imaginario del celuloide", Scripta Nova. Revista electrónica de Geografía y Ciencias Sociales, Vol. VII, 146.

Delleuze, G. (1984). La imagen - movimiento. Estudios sobre el cine 1, Barcelona, Paidós.

DIETRICH, N. ed. (1996). Film Architecture: Set Designs from Metropolis to Blade Runner, New York, Prestel, 207 pp.

Gamir ORUETA, A. (2012). "La consideración del espacio geográfico y el paisaje en el cine", Scripta Nova. Revista electrónica de Geografía y Ciencias Sociales, Vol. XVI, 403, 36 pp.

Gamir Orueta, A.; Manuel Valdés, C. (2007). "Cine y geografía: espacio geográfico, paisaje y territorio en las producciones cinematográficas", Boletín de la Asociación de Geógrafos Españoles, 45, pp. 157 -190.

GANDINI, L. (1994). L'immagine della città americana nel cinema hoIlywoodiano, 1927-1932, Bologna, Clueb, 287 pp.

HAmbleY, John; Downing, Patricks (1979). The Art of Hollywood. Fifty Years of Art Direction, Londres, Thames Television, 130 pp.
Kennedy, Ch.; LUKInBEAL, Ch. (1997). "Towards a holistic approach to geographic research on film", Progress in Human Geography, 21, pp. 33 - 50.

Lefebvre, M. (2006). Landscape and Film, Londres - Nueva York, Routledge, $361 \mathrm{pp}$.

McGiluigan, P. (2003). Alfred Hitchcock. Una vida de luces y sombras, Madrid, T\&B Editores.

Païnı, D.; Cogeval, G. ed. (2000), Hitchcock and Art: Fatal Coincidences, Montreal Museum of Fine Arts/Mazzotta, Montreal.

RAmíREZ, Juan Antonio (1986). La arquitectura en el cine: Hollywood, la Edad de Oro, Madrid, Hermann Blume, 349 pp.

RelPH, E. (1987). The Modern Urban Landscape, Londres, Croom Helm.

Riambau, E. (1980). "Hollywood entre bastidores", Dirigido por..., 71, pp. 44-56.

Rosado, C.; Querol, P. (2006). Cine y turismo. Una nueva estrategia de promoción, Sevilla, Junta de Andalucia, $136 \mathrm{pp}$.

SORLIN, P. (2001). "El cine y la ciudad: una relación inquietante", Secuencias. Revista de historia del cine, 13, pp. 21 - 28.

Sрото, D. (2004). Alfred Hitchcock: la cara oculta del genio, Madrid, T\&B editores,

Truffaut, F. (2010). El cine según Hitchcock, Madrid, Alianza.

TUAN, Y. (1979). "Sight and Pictures", The Geographical Review, 69, 4, pp. $413-422$.

W.AA. (1956). CAHIERS DU CINÉMA, agosto- septiembre, n. ${ }^{\circ} 62$.

Wright, F.L. (1978). El futuro de la arquitectura, Barcelona, Poseidón. 
